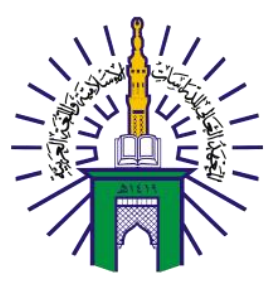

BUSTANUL FUQAHA:

JURNAL BIDANG HUKUM ISLAM

Vol. 2 No. 1 (2021): Hal. 59-77

EISSN: 2723-6021

Website: https://journal.stiba.ac.id

\title{
TRADISI AKKORONTIGI DALAM PERSPEKTIF HUKUM ISLAM (STUDI KASUS DI DESA BONTOSUNGGU, KECAMATAN BAJENG, KABUPATEN GOWA)
}

\section{AKKORONTIGI TRADITION IN THE PERSPECTIVE OF ISLAMIC LAW AND CUSTOMARY LAW (CASE STUDY IN BONTOSUNGGU VILLAGE, BAJENG SUB-DISTRICT, GOWA REGENCY)}

\author{
Ahmad Syaripudin \\ Sekolah Tinggi Ilmu Islam dan Bahasa Arab (STIBA) Makassar \\ ahmadsyaripudin@stiba.ac.id \\ Akhmad Hanafi Dain Yunta \\ Sekolah Tinggi Ilmu Islam dan Bahasa Arab (STIBA) Makassar \\ ahmadhanafi@gmail.com \\ Darussalam \\ Sekolah Tinggi Ilmu Islam dan Bahasa Arab (STIBA) Makassar \\ saharuddingassing1975@gmail.com
}

\begin{tabular}{|c|c|}
\hline Keywords : & ABSTRACT \\
\hline $\begin{array}{l}\text { Akkorontigi Tradition, } \\
\text { Bontosunggu Village, } \\
\text { Customary Law, Islamic Law. }\end{array}$ & $\begin{array}{l}\text { This study aims to determine and understand the akkkorontigi } \\
\text { tradition in the Perspective of Islamic Law and Customary Law that } \\
\text { occurred in Bontosunggu Village, Bajeng District, Gowa Regency. } \\
\text { This type of writing is field research (field research) using historical } \\
\text { approaches, social expectations, anthropological approaches and } \\
\text { religious approaches, then data collection methods using interview } \\
\text { and observation techniques the author tries to argue about the object } \\
\text { being studied in accordance with the reality that occurs in society. } \\
\text { The results showed that in carrying out marriage, the akkorontigi } \\
\text { tradition is one of a series of wedding processions that cannot be } \\
\text { missed and is a habit of their ancestors that has existed since time } \\
\text { immemorial. The akkorontigi event is a series of sacred events that } \\
\text { are attended by all relatives and invited guests which contain values } \\
\text { that are meaningful so that the bride's family can live in harmony. } \\
\text { However, in practice, it is necessary to present good intentions and } \\
\text { distance oneself from thoughts or beliefs that lead to the shirking of } \\
\text { the symbols of tools and objects used in Akkorongtigi. Even so, } \\
\text { Akkorongtigi can be preserved by applying several solutions in its } \\
\text { implementation, such as wearing clothes that are not tight and } \\
\text { covering the genitals, and not shaking hands for non-mahrams. }\end{array}$ \\
\hline \multirow{2}{*}{$\begin{array}{l}\text { Kata kunci : } \\
\text { Tradisi Akkorontigi, Hukum } \\
\text { Islam, Hukum Adat, Desa } \\
\text { Bontosunggu }\end{array}$} & ABSTRAK \\
\hline & $\begin{array}{l}\text { Penelitian ini bertujuan untuk mengetahui dan memahami tradisi } \\
\text { Akkkorontigi dalam perspektif hukum Islam dan hukum adat yang } \\
\text { terjadi di Desa Bontosunggu Kecamatan Bajeng Kabupaten Gowa. } \\
\text { Jenis penelitian ini adalah penelitian field research (penelitian } \\
\text { lapangan) dengan menggunakan pendekatan sejarah, pendekatan } \\
\text { sosial, pendekatan antorpologi dan pendekatan agama. Selanjutnya }\end{array}$ \\
\hline
\end{tabular}




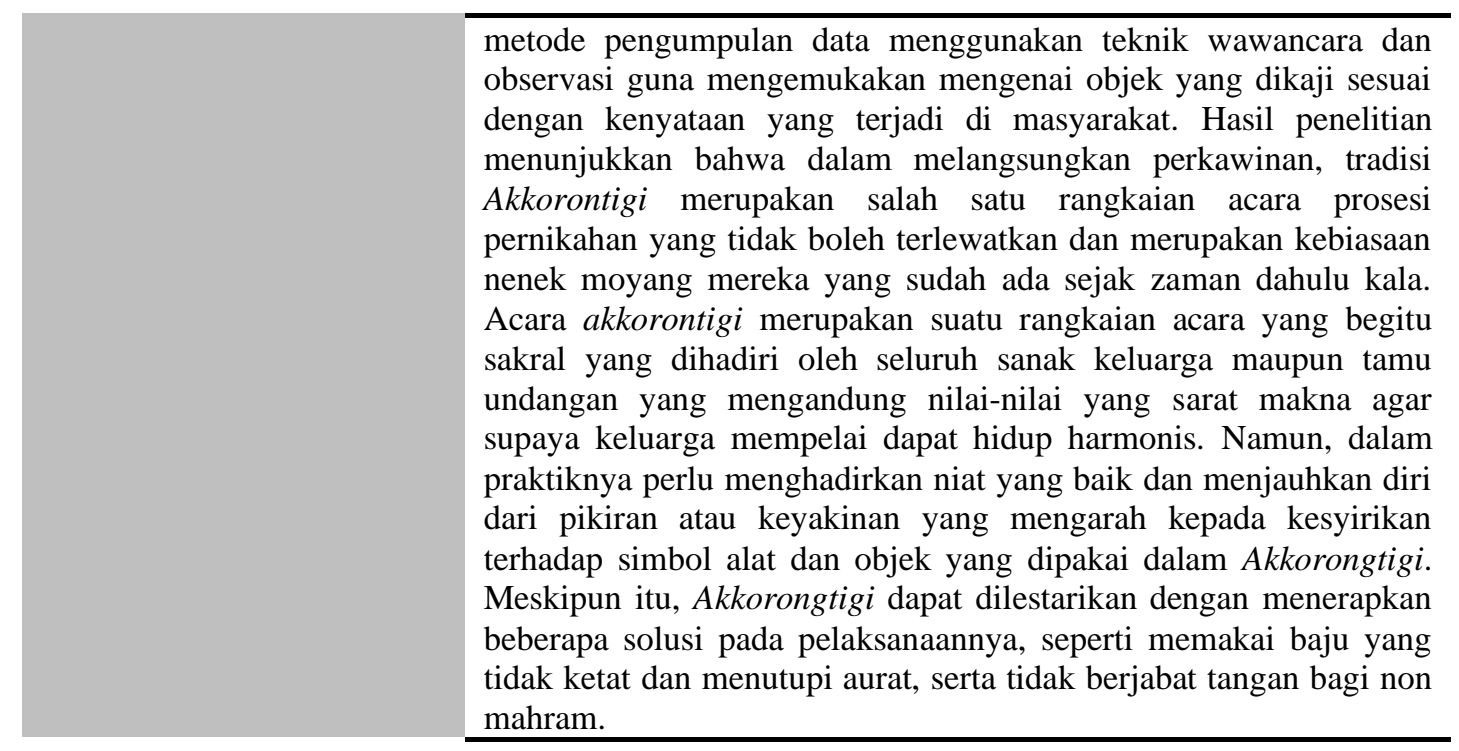

Diterima: 11 Februari 2021; Direvisi: 4 April 2021; Disetujui: 8 April 2021; Tersedia online: 23 April 2021.

How to cite: Syaripudin, Ahmad., Akhmad Hanafi Dain Yunta and Darussalam, "Tradisi Akkorontigi dalam Perspektif Hukum Islam (Studi Kasus di Desa Bontosunggu Kecamatan Bajeng Kabupaten Gowa)," BUSTANUL FUQAHA: Jurnal Bidang Hukum Islam 2, No.1 (April 23, 2021): 59-77. doi: https://doi.org/10.36701/bustanul.v2i1.300

\section{PENDAHULUAN}

Upacara-upacara keagamaan dalam kehidupan suatu suku, kelompok, atau persekutuan dalam masyarakat biasanya merupakan unsur-unsur kebudayaan yang paling tampak realisasinya. Masyarakat yang percaya atas kebenaran agama sangat peka pada perbuatan dan tindakan keagamaan, terutama bila kegiatan itu dalam bentuk kegiatan upacara ${ }^{1}$. Masyarakat Makassar merupakan salah satu suku yang masih mempertahankan kebudayaan dan adat istiadatnya di Indonesia. Kebudayaan merupakan persoalan yang sangat kompleks dan luas, misalnya kebudayaan yang berkaitan dengan cara manusia hidup, adat istiadat dan tata krama. Kebudayaan sebagai bagian dari kehidupan, cenderung berbeda antara satu suku dengan suku lainnya, khususnya di Indonesia. Meskipun dalam berbagai tradisi yang hidup di masyarakat memiliki beragam tata cara pelaksanaannya, namun tidak sedikit dijumpai memiliki kesamaan antara satu tradisi dengan tradisi lainnya antar daerah di Indonesia ${ }^{2}$.

\footnotetext{
${ }^{1}$ Ahmad Saransi, Tradisi Masyarakat Islam di Sulawesi Selatan (Cet. I; Makassar: Lamanca Press, 2003), 1.

${ }^{2}$ Hendra Wijaya, and Fadlan Akbar. "Tradisi Te'nea dalam Perspektif Hukum Islam (Studi Kasus di Desa Majannang)." NUKHBATUL'ULUM: Jurnal Bidang Kajian Islam 6.1 (2020): 146.
} 


\section{BUSTANUL FUQAHA: \\ JURNAL BIDANG HUKUM ISLAM \\ Vol. 2 No. 1 (2021): Hal. 59-77 \\ EISSN: 2723-6021 \\ Website: https://journal.stiba.ac.id}

Salah satu adat istiadat yang masih dijunjung tinggi oleh masyarakat Makassar termasuk di Bontotangnga Desa Bontosunggu adalah adat perkawinan. Semua orang tua mengharapkan agar anaknya dapat tumbuh dan berkembang supaya ketika besar dapat menikah dengan ramai yang disebut dengan istilah "Bunting Lompo". Harapan ini terwujud apabila sang anak baik laki-laki maupun perempuan mengikuti aturan adat dan taat melakukan ajaran agama yang dianutnya ${ }^{3}$.

Agama Islam adalah paling mayoritas dianut oleh penduduk Sulawesi Selatan yang berjumlah sekitar delapan juta orang. Begitu kuatnya pengaruh agama Islam terhadap tatanan kehidupan masyarakat, sehingga terkadang sulit dibedakan antara tradisi lama orang Sulawesi Selatan yang tumbuh dari zaman animisme hingga era peradaban dengan tradisi yang dibentuk oleh masuknya Islam ${ }^{4}$. Salah satu adat pernikahan yang masih dijunjung tinggi oleh masyarakat Makassar termasuk di Bontotangnga Desa Bontosunggu Kecamatan Bajeng sampai saat ini adalah "Akkorontigi" atau biasa disebut oleh kebanyakan orang dengan istilah "Mappaccing". Akkorontigi merupakan salah satu rangkaian adat pesta pernikahan di kalangan masyarakat Makassar yang masih kental dengan adat istiadatnya.

Sehari sebelum resepsi pernikahan dan sebelum Akkorontigi atau malam Mappaccing dilakukan, pada siang harinya calon pengantin terlebih dahulu dimandi (diPassili). Dalam kepercayaan lokal, hal ini merupakan bagian upacara yang sangat sakral. Calon pengantin dimandikan dengan pakaian lengkap dan menggunakan air daun sirih dan beberapa kembang lainnya. Tentu saja bagian upacara ini selalu disertai pembacaan doa-doa dan mantra-mantra untuk mengusir roh-roh dan makhluk jahat. Pakaian yang dipakai mandi diserahkan pada yang memimpin upacara tersebut. Dengan diserahkannya pakaian tersebut berarti lenyap pula semua makhluk dan roh jahat yang akan merusak kehidupan pengantin dalam rumah tangganya kelak ${ }^{5}$. Pada malam harinya menjelang hari persandingan, seluruh keluarga tertentu dipersilahkan secara berturut-turut untuk meletakkan daun pacci di atas telapak tangan daun pengantin. Upacara inilah yang disebut Akkorontigi. Daun pacci diasosiasikan dengan kata paccing yang artinya bersih. Maksudnya ialah bahwa seluruh hadirin yang ikut dalam upacara Akkorontigi tersebut menyaksikan kebersihan dan kesucian hubungan perkawinan yang akan dijalin itu ${ }^{6}$.

Secara keseluruhan, prosesi upacara adat dalam pernikahan masyarakat Makassar masing-masing memiliki nilai budaya serta makna dan pesan yang terkandung di dalamnya. Secara khusus, adat Akkorontigi yang dilakukan di Desa Bontosunggu Kecamatan Bajeng Kabupaten Gowa ini memiliki hikmah yang mendalam, mengandung

\footnotetext{
${ }^{3}$ Daeng Kembong, Pappilajarang Basa Siagang Sasetera Mangkasarak SMP Kelas IX (Cet. I; Makassar: Makassar Press, 2003), 64.

${ }^{4}$ Ahmad Saransi, Tradisi Masyarakat Islam di Sulawesi-Selatan, (Cet. I; Lamacca Press, 2003), XXI.

${ }^{5}$ Ahmad Saransi, Tradisi Masyarakat Islam di Sulawesi-Selatan, 106.

${ }^{6}$ Ahmad Saransi, Tradisi Masyarakat Islam di Sulawesi-Selatan, 106.
} 
nilai kesucian dan kebersihan dengan tujuan untuk mensucikan diri dari segala sesuatu. Baik suci secara lahir maupun batin agar memperoleh keselamatan, kesejahteraan dalam mengarungi bahtera rumah tangga kelak dan menjadi keluarga yang sakinah, mawadah, wa rahmah. Namun, yang menimbulkan pertanyaan adalah, apakah adat Akkorongtigi sesuai dengan sunah Rasulullah saw. atau syariat Islam?. Untuk itu, penulis mengkajinya lebih mendalam dan berupaya menemukan hukum Islam terhadap tradisi tersebut.

\section{PEMBAHASAN}

\section{Tradisi Akkorontigi di Desa Bontosunggu, Kecamatan Bajeng, Kabupaten Gowa}

Desa Bontosunggu termasuk wilayah yang berada di Kecamatan Bajeng dengan luas wilayah Desa Bontosunggu $\pm 312,59 \mathrm{~km}^{2}$. Kepadatan penduduk sudah mencapai 6.566 jiwa penduduk tetap. Letak geografis Desa Bontosunggu yang berada di wilayah Kecamatan Bajeng Kabupaten Gowa memiliki potensi berkembang dalam sektor pertanian dan pengembangan usaha ekonomi kerakyatan ${ }^{7}$. Keseharian masyarakat Desa Bontosunggu umumnya adalah bercocok tanam, bertani, buruh tani, dan beternak, wiraswasta, buruh bangunan, berdagang, dan yang lainnya. Mengingat keadaan wilayah Desa Bontosunggu adalah dataran rendah $^{8}$, maka masyarakat umumnya aktif mengelola lahan pertanian dan dengan menanam padi, dengan menggunakan cara yang sederhana dan konvensional dan hasil panen belum seutuhnya menemukan harga yang sebanding dengan pekerjaan tersebut. Kendala utamanya adalah naik turunnya harga perdagangan tanaman jagung dan padi dan serangan hama, tikus dan lain-lain, juga pada saat panen raya sering turun drastis sementara harga bahan-bahan pertanian cukup tinggi dan terkadang tidak mampu bertahan lama sehingga banyak yang belum sempat menjual hasil panennya sementara harga hasil panen sudah turun'.

Acara Akkorontigi merupakan rangkaian dari berbagai macam adat pesta perkawinan masyarakat Makassar, khususnya di Desa Bontosunggu. Upacara Akkorontigi merupakan salah satu ritual dalam prosesi pernikahan dengan menggunakan daun pacar yang mempunyai makna suci atau melambangkan kesucian. Menjelang pernikahan diadakan, masyarakat setempat terlebih dahulu melakukan kegiatan Akkorontigi yang artinya meletakkan tumbuhan daun pacar ke tangan calon mempelai. Melaksanakan kegiatan Akkorontigi, berarti calon pengantin telah siap untuk menghadapi apa yang akan mereka hadapi dalam mengarungi bahtera rumah tangga dengan membawa hati yang suci serta ikhlas terhadap semuanya. Konon, pada zaman dahulu proses Akkorontigi pernah dilaksanakan selama tiga hari berturut-turut, namun seiring dengan perkembangan

\footnotetext{
${ }^{7}$ Laporan Keterangan Pertanggungjawaban Kepala Desa (LKPKD) Akhir Tahun 2018.

${ }^{8}$ Asdar DM, A.Md., 35 Tahun, Sekretaris II Desa Bontosunggu, Wawancara, Bontotangnga Desa Bontosunggu, (5 Desember 2019).

${ }^{9}$ Asdar DM, A.Md., 35 Tahun, Sekretaris II Desa Bontosunggu, Wawancara, Bontotangnga Desa Bontosunggu, (5 Desember 2019).
} 


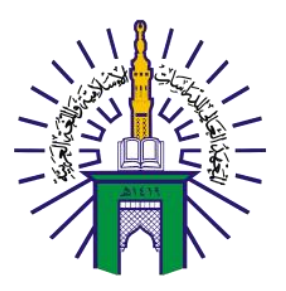

\section{BUSTANUL FUQAHA: \\ JURNAL BIDANG HUKUM ISLAM \\ Vol. 2 No. 1 (2021): Hal. 59-77 \\ EISSN: 2723-6021 \\ Website: https://journal.stiba.ac.id}

zaman, prosesi Akkorontigi hanya dilakukan satu hari saja. Entah apa penyebab berkurangnya waktu akkorontigi tersebut, namun sebagian masyarakat beralasan karena hal tersebut menyita banyak waktu sehingga pengeluaran pun semakin bertambah ${ }^{10}$. Menanggapi hal tersebut, akan larangan berlebih-lebihan, sangat erat kaitannya dengan apa yang telah difirmankan oleh Allah swt. dalam Al-Qur'an Qs. Al-An'am/6:141 yang berbunyi:

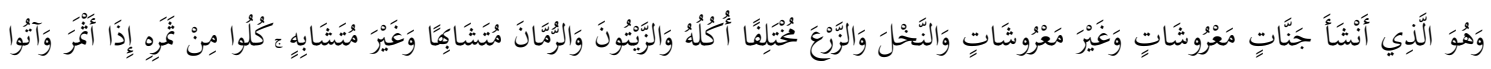

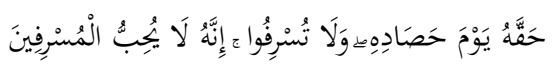

Terjemahnya:

"Dan dialah yang menjadikan kebun-kebun yang berjunjung dan yang tidak berjunjung, pohon kurma, tanam-tanaman yang bermacam-macam buahnya, zaitun dan delima yang serupa (bentuk dan warnanya) dan tidak sama (rasanya). makanlah dari buahnya (yang bermacam-macam itu) bila dia berbuah, dan tunaikanlah haknya di hari memetik hasilnya (dengan disedekahkan kepada fakir miskin); dan janganlah kamu berlebih-lebihan. Sesungguhnya Allah tidak menyukai orang yang berlebih-lebihan"11.

Akkorontigi merupakan kata sifat dan korontigi adalah kata kerja. Dalam masyarakat Desa Bontosunggu, kata tersebut sudah tidak asing untuk kita dengarkan di mana di dalamnya terdapat rangkaian yang begitu sakral dan dihadiri oleh seluruh keluarga calon mempelai. Tradisi tersebut mempunyai makna yang begitu mendalam dan memiliki harapan agar sang calon mempelai senantiasa bersih dan suci dalam menghadapi hari pernikahannya esok hari. Acara ini umumnya menggunakan daun pacar (leko' paccing) di mana yang meletakkan leko' paccing tersebut biasanya dari keluarga yang memiliki kehidupan yang bahagia, rumah tangganya tentram serta mempunyai kedudukan yang baik. Hal tersebut dimaksudkan agar calon mempelai tersebut dapat menjadi seperti mereka yang telah meletakkan leko' pacci tersebut kepada sang calon pengantin. Dalam masyarakat Bontosungggu, mereka beranggapan pula bahwa tidak ada yang tahu pasti kapan prosesi Akkorontigi tersebut mulai dilaksanakan, dan kapan acara tersebut ditetapkan sebagai salah satu rangkaian adat dari adat perkawinan, namun yang dapat dipahami oleh masyarakat setempat yaitu adat Akkorontigi tersebut dilakukan secara turun temurun mulai dari nenek moyang mereka hingga sampai ke generasi saat

\footnotetext{
${ }^{10}$ Nurliah, 57 Tahun, Anrong Bunting, Wawancara, Bontotangnga Desa Bontosunggu, (26 November 2019).

${ }^{11}$ Kementerian Agama Republik Indonesia, Al-Qur'an dan Terjemahnya, 146.
} 


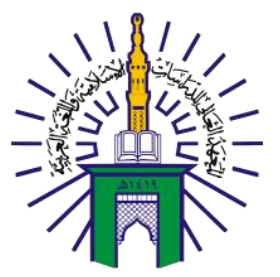

\section{BUSTANUL FUQAHA: \\ JURNAL BIDANG HUKUM ISLAM \\ Vol. 2 No. 1 (2021): Hal. 59-77 \\ EISSN: 2723-6021 \\ Website: https://journal.stiba.ac.id}

ini, bahkan ada orang tua (tau toa) yang beranggapan bahwa tradisi tersebut sudah ada sejak agama Islam masuk ke daerah Makassar khususnya di Desa Bontosunggu ${ }^{12}$.

Dalam perkembangan selanjutnya, istilah Akkorontigi lebih dikenal sebagai lambang kesucian dan kebersihan. Tradisi Akkorontigi pun merupakan tradisi yang sudah mendarah daging di suku Makassar. Namun, ketika Islam datang maka prosesi ini mengalami sinkretisme saking kuatnya pengaruh agama Islam dalam suatu masyarakat. Oleh karena itu, idealnya, masyarakat yang sejahtera adalah masyarakat yang berpegang teguh pada ajaran agama Allah swt. seperti yang telah tertulis dalam Al-Qur'an surah AnNisā/4:59 yang berbunyi:

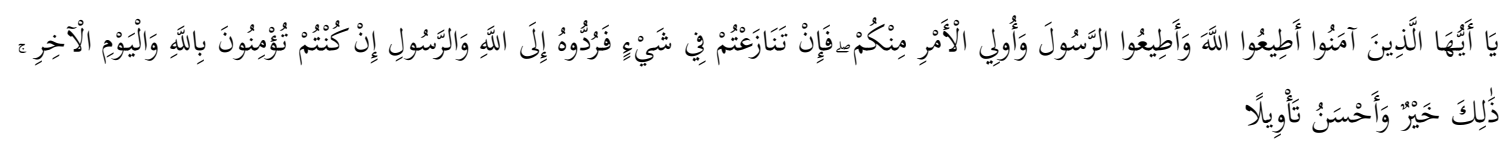

Terjemahnya:

"Kemudian jika kamu berlainan Pendapat tentang sesuatu, Maka kembalikanlah ia kepada Allah (Alquran) dan Rasul (Sunahnya), jika kamu benar-benar beriman kepada Allah dan hari kemudian. yang demikian itu lebih utama (bagimu) dan lebih baik akibatnya"13.

Berbicara tentang kuatnya pengaruh Islam yang masuk ke dalam suatu masyarakat, hal tersebut sangat dirasakan oleh masyarakat di Desa Bontosunggu khususnya dalam menanggapi prosesi Akkorontigi. Saat ini, proses Akkorontigi yang dilakukan oleh masyarakat setempat sudah tak semegah dan tak sesempurna seperti yang telah dilakukan oleh orang-orang terdahulu yang ada di masyarakat tersebut namun halhal yang berkaitan dengan tradisi Akkorontigi masih tetap terjaga dan masih tetap menjadi pelengkap sebelum memasuki pesta perkawinan di kalangan masyarakat Makassar khususnya di Desa Bontosunggu ${ }^{14}$.

Dalam menanggapi hal tersebut, terkadang ada sebagian masyarakat di Desa Bontosunggu yang tidak melaksanakan ritual tersebut karena beranggapan bahwa hal tersebut hanyalah mitos akibat kurangnya pemahaman orang-orang terdahulu dalam menanggapi dan mempercayai makna yang terkandung dalam proses Akkorontigi dan faktanya tidak ada hal-hal buruk yang menimpa mereka yang tidak melakukan ritual Akkorontigi akan tetapi tidak dapat dipungkiri bahwa dalam hal ini, masih banyak masyarakat setempat yang melakukan tradisi Akkorontigi itu sendiri karena memiliki

\footnotetext{
${ }^{12}$ Daeng Kanang (34 tahun), Pemangku adat, Wawancara, Bontotangnga Desa Bontosunggu, 25 November 2019.

${ }^{13}$ Kementerian Agama Republik Indonesia, Al-Qur'an dan Terjemahnya, 87.

${ }^{14}$ Daeng Kanang (66 tahun), Pemangku adat, Wawancara, Bontotangnga Desa Bontosunggu, 27 November 2019.
} 


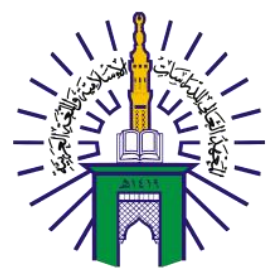

\section{BUSTANUL FUQAHA: \\ JURNAL BIDANG HUKUM ISLAM \\ Vol. 2 No. 1 (2021): Hal. 59-77 \\ EISSN: 2723-6021 \\ Website: https://journal.stiba.ac.id}

keyakinan yang kuat akan makna dan pesan yang terkandung dalam ritual tersebut ${ }^{15}$. Sebelum melaksanakan prosesi Akkorontigi, terlebih dahulu pihak keluarga melengkapi segala peralatan yang harus dipenuhi, seperti bantal, daun pacar, daun pisang, lilin, beras, sarung sutera, jagung (biralle) dan lain-lain. Tujuan dari Akkorontigi adalah untuk membersihkan jiwa dan raga calon mempelai sebelum mengarungi bahtera rumah tangga. Secara umum, rangkaian dalam melangsungkan proses Akkorontigi yang pernah terjadi dalam masyarakat di Desa Bontosunggu Kecamatan Bajeng Kabupaten Gowa adalah sebagai berikut:

Appassili. Sebelum melaksanakan prosesi Akkorontigi, maka terlebih dahulu diadakan proses Appassili (mandi uap). Hal tersebut bertujuan agar sang calon mempelai dapat segar bugar serta dapat membersihkan dan menenangkan jiwa dari hal-hal buruk sebelum hari pernikahannya. Oleh karena itu, pemilihan waktu ritual ini dilaksanakan di pagi hari. Adapun bahan yang digunakan saat prosesi Appassili tersebut berlangsung yaitu: air, wajan, kelapa muda, daun pisang, kemudian calon mempelai duduk di depan pintu menghadap utara sambil dimandikan oleh perias pengantin (Anrong Bunting) ${ }^{16}$.

Pembacaan Barazanji. Dalam masyarakat di Desa Bontosunggu Kecamatan Bajeng Kabupaten Gowa, pembacaan Barazanji pernah dilakukan oleh masyarakat setempat namun tidak semua masyarakat melakukan ritual dikarenakan ritual yang dilakukan sangat berkaitan erat dengan ajaran Islam, namun ada hal-hal yang mengganjal masyarakat setempat seperti takut akan terjatuh dalam kemusyrikan, sehingga banyak masyarakat yang lebih memilih untuk tidak melakukan ritual tersebut. Secara umum, dalam pembacaan Barazanji ini dipimpin oleh orang-orang yang telah mengerti agama, atau ulama-ulama atau imam yang telah mengerti ajaran Islam sesuai dengan apa yang diyakininya terhadap orang tersebut. Sebagian masyarakat juga menganggap bahwa proses Barazanji merupakan salah satu bentuk syiar Islam yang dapat meningkatkan kecintaan kepada Rasulullah saw. Di sisi lain, ada juga yang meyakini bahwa Barazanji merupakan suatu amalan yang dapat mendatangkan berkah serta mempermudah rezeki dan menjauhkan dari malapetaka. ${ }^{17}$

Appatamma' (Khatam Al-Qur'an). Ritual ini adalah ritual yang terpenting dalam adat Akkorontigi, mereka beranggapan bahwa ada baiknya sebelum proses Akkkorontigi dilaksanakan calon mempelai menamatkan atau mengkhatamkan Al-Qur'an terlebih dahulu walaupun yang dibaca hanyalah lima sampai tujuh surat terakhir dalam Al-Qur'an. Ritual Appatamma' dipimpin oleh guru mengaji waktu kecil atau imam dusun di lokasi sang mempelai. Dalam hal ini, nilai-nilai budaya yang terkandung didalamnya

${ }^{15}$ Daeng Kanang (66 tahun), Pemangku adat, Wawancara, Bontotangnga Desa Bontosunggu, 27 November 2019.

${ }^{16}$ Nurliah, 57 Tahun, Anrong Bunting, Wawancara, Bontotangnga Desa Bontosunggu, (26 November 2019).

${ }^{17}$ Zaenab, 62 Tahun, Objek atau Pelaku Akkorontigi, Wawancara, Bontotangnga Desa Bontosunggu, (9 Desember 2019). 


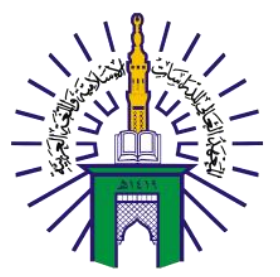

\section{BUSTANUL FUQAHA: \\ JURNAL BIDANG HUKUM ISLAM \\ Vol. 2 No. 1 (2021): Hal. 59-77 \\ EISSN: 2723-6021 \\ Website: https://journal.stiba.ac.id}

sangatlah kental karena merupakan sifat dan hal-hal yang sangat penting dalam kehidupan manusia. Masyarakat setempat memaknai bahwa Appatamma' ini mengajarkan dan mengingatkan kita untuk kembali kepada ayat-ayat suci Al-Qur'an dan senantiasa mendapatkan berkah dan rida dari Allah swt. Hal ini sejalan dengan apa yang telah difirmankan oleh Allah swt. dalam Qs. Ar-Rūm/30:21 yang berbunyi:

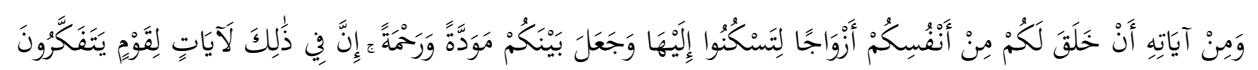

Terjemahnya:

"Dan di antara tanda-tanda kekuasaan-Nya ialah Dia menciptakan untukmu isteri-isteri dari jenismu sendiri, supaya kamu cenderung dan merasa tenteram kepadanya, dan dijadikan diantaramu rasa kasih dan sayang. Sesungguhnya pada yang demikian itu benar-benar terdapat tanda-tanda bagi kaum yang berpikir" $"$.

Ayat tersebut menjelaskan agar supaya ikatan suci yang kita bangun selalu harmonis, bahagia dan sejahtera untuk menjalankan rumah tangga yang akan dibangun bersama pasangannya dan mendapatkan rida dari Allah swt.

Akkorontigi. Akkorontigi merupakan suatu kegiatan yang bertujuan untuk ungkapan tentang kesucian lahir dan batin yang dimiliki oleh calon pengantin dan keluarganya. Dalam proses pelaksanaanya, diletakkan sebuah bantal di depan calon pengantin sebagai lambang kehormatan. Bantal sering diidentikkan di kepala, dan merupakan titik sentral bagi aktivitas manusia. Diharapkan dengan simbol ini, para calon pengantin dapat memahami identitas dirinya sebagai makhluk yang mulia dan memiliki kehormatan oleh sang pencipta dibandingkan dengan makhluk-makhluk yang lainnya. Terkhusus untuk calon mempelai laki-laki, juga diharapkan agar ia dapat mengetahui tabiat dirinya sebagai kepala keluarga yang harus mengayomi dan membimbing keluarganya. Dalam prosesi acara Akkorontigi, maka calon pengantin dirias dengan menggunakan baju adat Makassar (Baju Bodo) kemudian calon pengantin dibawa ke Lamming (panggung untuk calon pengantin) untuk memulai prosesi tersebut. Dalam proses pelaksanaannya, maka disiapkanlah berbagai macam peralatan yang mengandung makna tersendiri dalam mengarungi bahtera rumah tangga yang selalu didasari oleh estetika dalam mencapai kebahagiaan tersebut di dunia maupun di akhirat. Adapun peralatan sebelum melakukan tradisi tersebut antara lain: 1) Pa'lungang (Bantal); 2) Bombong Unti (Daun pucuk pisang); 3) Leko' Paccing (daun pacar); 4) Tai Bani (lilin merah); 5) Berasa' (Beras); 6) Benno (Kembang beras); 7) Cangkiri’ Paccing (Wadah paccing).

\footnotetext{
${ }^{18}$ Kementerian Agama Republik Indonesia, Al-Qur'an dan Terjemahnya, 69.
} 


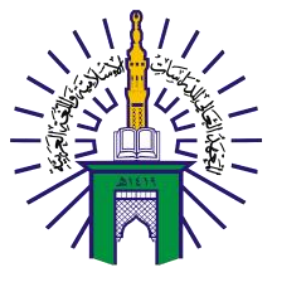

\section{BUSTANUL FUQAHA: \\ JURNAL BIDANG HUKUM ISLAM \\ Vol. 2 No. 1 (2021): Hal. 59-77 \\ EISSN: 2723-6021 \\ Website: https://journal.stiba.ac.id}

Proses pelaksanaan Akkorontigi biasanya baru dilaksanakan ketika para sanak keluarga dan tamu undangan yang telah dimandatkan untuk meletakkan Paccing sudah hadir. Acara tersebut diawali dengan pembacaan Barazanji atau selawat nabi, kemudian Appatamma' atau khatam Al-Qur'an yang dipimpin oleh imam dusun kemudian setelah itu calon pengantin di bawah ke Lamming, maka proses peletakan Paccing yang biasanya dimulai oleh imam dusun, kemudian sanak keluarga lalu tamu undangan yang diberikan mandat untuk meletakkan Paccing itu segera dimulai ${ }^{19}$.

Dalam proses pelaksanaannya, para mandat yang diberikan tugas untuk meletakkan Paccing mengambil Leko' Paccing yang sudah dihaluskan (daun pacar) di Mangko' Paccing (wadah Paccing) kemudian diletakkan ke tangan calon mempelai lalu setelah itu diletakkan pula didahi sang mempelai yang melambangkan kesucian dan kebersihan. Sebelum prosesi Akkorontigi berakhir, maka acara tersebut ditutup dengan doa. Setelah itu para tamu undangan dipersilahkan untuk mencicipi makanan yang telah disediakan oleh tuan rumah.

Seiring dengan berkembangnya zaman, tradisi Akkorontigi yang dilakukan di Desa Bontosunggu Kecamatan Bajeng Kabupaten Gowa tidak lagi sesempurna yang dulu karena pengaruh Islam yang sangat kuat di Desa tersebut sehingga ritual Akkorontigi mulai mengikis sehingga dalam proses pelaksanaannya terkadang mereka tidak melakukan prosesi Barazanji dan Appatamma' atau yang lainnya karena takut hal tersebut bertentangan dengan syariat Islam, bahkan ada juga sebagian masyarakat yang sudah tidak melaksanakan tradisi tersebut sebelum melakukan pernikahan. Walaupun demikian, segala sesuatu yang berkaitan dengan adat tradisi Akkorontigi yang mengandung pesan dan makna yang begitu sakral sangat susah untuk dihilangkan walaupun hal tersebut sejalan dengan proses berkembangnya zaman teknologi informasi dan komunikasi ${ }^{20}$.

\section{Makna yang Terkandung dalam Tradisi Akkorontigi di Desa Bontosunggu, Kecamatan Bajeng, Kabupaten Gowa Menurut Pandangan Hukum Adat}

Tradisi Akkorontigi merupakan rangkaian adat pernikahan di Desa Bontosunggu Kecamatan Bajeng Kabupaten Gowa. Dalam prosesi Akkorontigi, ia memiliki makna simbolik yang terkandung didalamnya. Manusia dalam menjalani kehidupannya biasanya tidak bisa melepaskan diri dari dunia simbol. Teori simbol berasal dari Yunani yaitu syimballo (menarik kesimpulan berarti memberi kesan). Simbol atau lambang sebagai sarana atau mediasi untuk membuat dan menyampaikan suatu pesan, menyusun sistem epistimologi dan keyakinan yang dianut ${ }^{21}$. Adapun dalam kehidupan

\footnotetext{
${ }^{19}$ Hapipa Daeng Calla, 71 Tahun, Masyarakat Desa Bontosunggu, Wawancara, Bontotangnga Desa Bontosunggu, (7 Desember 2019).

${ }^{20}$ Hapipa Daeng Calla, 71 Tahun, Masyarakat Bontosunggu, Wawancara, Bontotangnga Desa Bontosunggu, (7 Desember 2019).

${ }^{21}$ Sujono Soekamto, Sosiologi Suatu Pengantar, (Jakarta: Raja Grafindo, 2001), 187.
} 

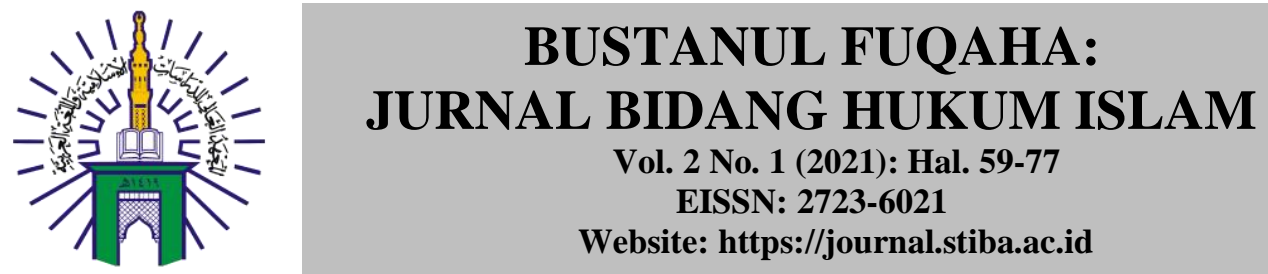

sehari-hari manusia sering membicarakan tentang simbol, begitu pula dengan kehidupan manusia tidak mungkin tidak berurusan dengan hasil kebudayaan. Akan tetapi, setiap hari orang melihat, mempergunakan bahkan terkadang merusak kebudayaan tersebut.

Kebudayaan sendiri merupakan hasil ciptaan manusia sebagai angota masyarakat, maka yang jelas tidak ada manusia yang tidak memiliki kebudayaan dan juga sebaliknya tidak ada kebudayaan tanpa masyarakat, jadi masyarakat mempunyai peran sebagai wadah dan pendukung dari suatu kebudayaan ${ }^{22}$. Masyarakat merupakan makhluk berbudaya, sedangkan kebudayaan merupakan ukuran tingkah laku serta kehidupan manusia. Dan masyarakat Makassar pada hakekatnya memiliki kebudayaan yang khas sebagai masyarakat bersimbolis. Seperti dalam kehidupan sehari-hari, simbol tidak hanya berguna sebagai tempat mediasai untuk menyampaikan suatu pesan tertentu, menyusun epistemologi dan keyakinan yang telah dianut ${ }^{23}$. Dalam keragaman pemikiran mengenai simbol tersebut, maka ada dua sumber utama yang disepakati bersama yaitu: Pertama, simbol telah dan sampai sekarang ini masih mempunyai peranan penting dalam kehidupan manusia; Kedua, simbol merupakan alat yang kuat untuk memperluas pengetahuan kita, merangsang daya imajinasi serta dapat memperdalam pengetahuan kita. Selama manusia mencari arti dari sebuah kehidupan, manusia tidak pernah lepas dari kata simbol.

Dalam proses upacara Akkorontigi yang terjadi di Desa Bontosunggu Kecamatan Bajeng Kabupaten Gowa, makna yang terkandung didalamnya selalu dilakukan pada setiap upacara pernikahan adat di Kabupaten Gowa, khususnya di Kecamatan Bajeng Desa Bontosunggu, karena mengandung simbol-simbol atau maksud yang baik dengan tujuan untuk membersihkan jiwa dan raga sang mempelai sebelum mengarungi bahtera rumah tangganya. Oleh karena itu, tradisi Akkrontigi merupakan pelengkap dalam pesta perkawinan di Sulawesi Selatan khususnya di Kabupaten Gowa, namun ketika Islam datang maka prosesi ini mengalami sinkritisme dan berbaur dengan ajaran Islam.

\section{Makna yang Terkandung dalam Tradisi Akkonrontigi di Desa Bontosunggu Kecamatan Bajeng Kabupaten Gowa Menurut Pandangan Hukum Islam}

Jika ditinjau dari sudut pandang Islam, Al-Qur'an sebagai pedoman hidup telah menjelaskan bagaimana kedudukan tradisi (adat-istiadat) dalam agama itu sendiri. Oleh karena nilai-nilai yang tertulis dalam sebuah tradisi dipercaya dapat mengantarkan keberuntungan, kesuksesan, kelimpahan dan keberhasilan bagi masyarakat tersebut. Akan tetapi eksistensi adat-istiadat tersebut juga tidak sedikit menimbulkan polemik jika

\footnotetext{
${ }^{22}$ Sujono Soekamto, Sosiologi Suatu Pengantar, (Jakarta: Raja Grafindo, 2001), 188.

${ }^{23}$ Nurliah, 57 Tahun, Anrong Bunting, Wawancara, Bontotangnga Desa Bontosunggu, (26 November 2019).
} 


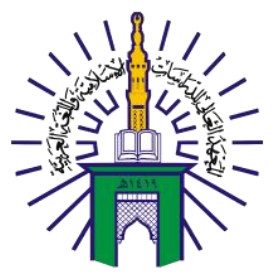

\section{BUSTANUL FUQAHA: \\ JURNAL BIDANG HUKUM ISLAM \\ Vol. 2 No. 1 (2021): Hal. 59-77 \\ EISSN: 2723-6021 \\ Website: https://journal.stiba.ac.id}

ditinjau dari kacamata Islam $^{24}$. Oleh karena itu, sebelum melaksanakan sesuatu, hendaknya mengetahui dasar dan nilai yang terkandung padanya, agar hal tersebut dapat lebih baik hasilnya dan bermanfaat bagi pelaku sendiri dan orang lain dan tidak membahayakan dirinya baik untuk dunianya maupun akhiratnya. Allah swt. berfirman dalam Al-Qur'an Qs. Al-Isrā/17:36 yang berbunyi:

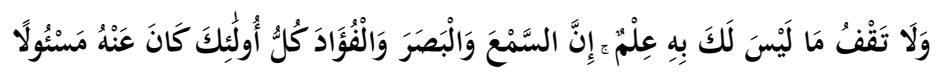

Terjemahnya:

"Dan janganlah kamu mengikuti apa yang kamu tidak mempunyai pengetahuan tentangnya. Sesungguhnya pendengaran, penglihatan dan hati, semuanya itu akan diminta pertanggungan jawabnya" 25 .

Sebelum membahas makna Akkorontigi dalam pandangan hukum Islam, terlebih dahulu akan dikemukakan sorotan hukum Islam tentang adat. Mengingat tradisi Akkorontigi termasuk salah satu rangkaian adat dalam prosesi perkawinan, maka prosesi perkawinan masyarakat di Desa Bontosunggu Kecamatan Bajeng Kabupaten Gowa dan masyarakat Makassar pada umumnya sangat berkaitan dengan istilah Al-'Urf. Dari segi bahasa artinya mengetahui ${ }^{26}$. Kemudian dipakai dalam arti, sesuatu yang diketahui, dikenal, dianggap baik dann diterima oleh pikiran yang sehat ${ }^{27}$. Sedangkan menurut istilah, ialah apa-apa yang dibiasakan oleh masyarakat dan dijalankan terus menerus, baik berupa perkataan maupun perbuatan. Menurut para ahli syariat tidak ada perbedaan antara $A l$-'Urf dengan adat ${ }^{28}$. Adat (kebiasaan) itu berasal dari kata $M u$ 'awadah yang artinya mengulang-ulangi. Oleh karena itu, dengan makna berulang-ulang maka jadilah hal itu terkenal dan dipandang baik oleh jiwa dan akal.

Menyoal tentang Akkorontigi artinya berbicara tentang rangkaian tradisi atau adat dari berbagai macam rangkaian adat sebelum melaksanakan pesta pernikahan suku Makassar khususnya di Desa Bontosunggu Kecamatan Bajeng Kabupaten Gowa. Tradisi Akkorontigi merupakan upaya manusia untuk membersihkan dan mensucikan diri dari hal-hal yang tidak baik sebelum melangsungkan pernikahan. Dengan keyakinan bahwa tujuan yang baik harus didasari oleh niat dan upaya yang baik pula. Adapun dengan

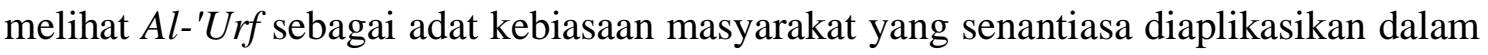

${ }^{24}$ Nuraeni Novira dan Auliani Ahmad, (2019), “Tinjauan Akidah Islam Terhadap Adat Mappalili di Balla Lompoa Kelurahan Baju Bodoa Kecamatan Maros Baru Kabupaten Maros Sulawesi Selatan”, NUKHBATUL 'ULUM: Jurnal Bidang Kajian Islam, 5(1), 20.

${ }^{25}$ Kementerian Agama Republik Indonesia, Al-Qur'an dan Terjemahnya, 285.

${ }^{26}$ Ahmad Hanafi, Pengantar dan Sejarah Hukum Islam (Cet.II; Jakarta: Bulan Bintang, 1997), 89.

${ }^{27}$ Abd. Gaffar, Peranan Al-'urf dalam Mengistimbatkan Hukum Islam, Skripsi, Mangkoso, Fakultas Syariah STAI DDI Mongkoso, 2003, 37.

${ }^{28}$ Ahmad Abd. Madjid, Muhādarat fĭ Ushul-al-Fiqih, (Cet.IV; Pasuruan: Garoeda Buana Indah, 1994), 84. 


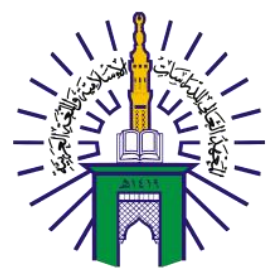

\section{BUSTANUL FUQAHA: \\ JURNAL BIDANG HUKUM ISLAM \\ Vol. 2 No. 1 (2021): Hal. 59-77 \\ EISSN: 2723-6021 \\ Website: https://journal.stiba.ac.id}

kehidupan mereka, apakah itu lewat perkataan atau perbuatan. Untuk itu, jika ditinjau dari sudut pandang hukum Islam maka $A l^{-} U r f$ terbagi menjadi dua yaitu: ${ }^{29}$

Pertama, Al-'Urf yang benar adalah adat kebiasaan yang dilakukan oleh masyarakat yang tidak bertentangan dengan dalil syara', tidak menghalalkan yang haram dan tidak membatalkan yang wajib, misalnya adat kebiasaan yang berlaku dalam dunia perdagangan, yaitu indent (pembelian barang dengan cara memesan terlebih dahulu). Adat kebiasan dalam pembayaran mahar secara kontan atau hutang, adat kebiasaan melamar seorang wanita dengan memberikan sesuatu sebagai hadiah, bukan sebagai mahar dan sebagainya; Kedua, Al-'Urf Fasid ialah kebiasaan yang dilakukan oleh masyarakat yang berlawanan dengan ketentuan syariat, menghalalkan yang haram atau membatalkan ynag wajib. Misalnya kebiasaan dalam akad perjanjian yang bersifat riba, mencari dana kupon dengan hadiah, menaruh pajak hasil perjudian atau perbuatan maksiat lainnya.

Dengan demikian, berdasarkan narasi di atas, maka dalam hukum Islam, tradisi Akkorontigi dalam perkawinan termasuk wadah silaturrahmi yang baik. Hal ini dikarenakan dalam proses Akkorontigi dihadiri oleh kerabat dari pihak ayah dan ibu calon mempelai untuk memberikan restu kepada calon pengantin. Kehadiran keluarga, kerabat dan para tokoh agama dalam prosesi Akkorontigi ini memberikan makna untuk saling mendoakan antar sesama ${ }^{30}$. Untuk itu, berbicara tentang keutamaan silaturahmi antar sesama, Allah swt. berfirman dalam Al-Qur'an Qs. Al-Nisa/4:1, yang berbunyi:

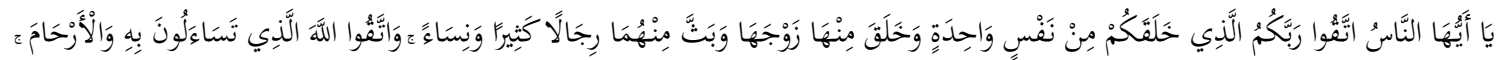

$$
\begin{aligned}
& \text { إِنَّ النَّ كَانَ عَلَيْكُمْ رَقِيبًا }
\end{aligned}
$$

Terjemahnya:

"Hai sekalian manusia, bertakwalah kepada Tuhan-mu yang telah menciptakan kamu dari seorang diri, dan dari padanya Allah menciptakan isterinya; dan dari pada keduanya Allah memperkembangbiakkan laki-laki dan perempuan yang banyak. Dan bertakwalah kepada Allah yang dengan (mempergunakan) namaNya kamu saling meminta satu sama lain, dan (peliharalah) hubungan silaturrahim. Sesungguhnya Allah selalu menjaga kamu"31.

Di kalangan masyarakat Makassar, ada sikap atau ucapan yang menunjukkan bahwa mereka tidak menyetujui pelaksanaan perkawinan. Kehadiran kerabat dalam

\footnotetext{
${ }^{29}$ Muhtar Yahya, Fatehurahman, Dasar-Dasar Pembinaan Hukum Fikih Islam (Cet. I; Bandung: Al-Ma'rif, 2001), 110.

${ }^{30}$ Daeng Kanang, 66 Tahun, Anrong Pemangku Adat, Wawancara, Bontotangnga Desa Bontosunggu, (26 November 2019).

${ }^{31}$ Kementerian Agama Republik Indonesia, Al-Qur'an dan Terjemahnya, 77.
} 


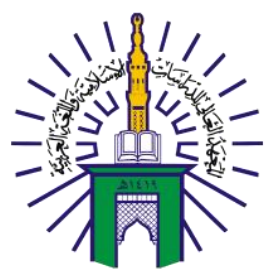

\section{BUSTANUL FUQAHA: \\ JURNAL BIDANG HUKUM ISLAM \\ Vol. 2 No. 1 (2021): Hal. 59-77 \\ EISSN: 2723-6021 \\ Website: https://journal.stiba.ac.id}

prosesi ini, apalagi diberi kesempatan untuk ikut meletakkan Paccing pada kedua telapak tangan calon mempelai dapat memberikan makna bahwa mereka merestui pernikahan tersebut. Makna lain yang terkandung dalam prosesi Akkorontigi di Desa Bontosunggu Kecamatan Bajeng Kabupaten Gowa secara khusus, dan Masyarakat Makassar secara umum, yaitu memberikan simbol kesucian dan persaksian. Gadis atau perjaka yang melaksanakan tradisi Akkorontigi adalah sebagai lambang tentang kesucian dirinya dan sebagai bukti bahwa masih perawan dan perjaka. Olehnya itu, rangkaian acara perkawinan yang secara kebetulan untuk yang kedua kalinya menikah atau lebih, apalagi jika statusnya duda atau janda, tidak lagi diadakan tradisi Akkorontigi $i^{32}$.

Hal ini sejalan dengan tuntunan hukum Islam agar kehormatan dan kesucian seseorang tetap dijaga dengan baik sampai ke jenjang pernikahan. Allah swt. berfirman dalam Al-Qur'an Qs. Al-Nūr/24: 30-31 yang berbunyi:

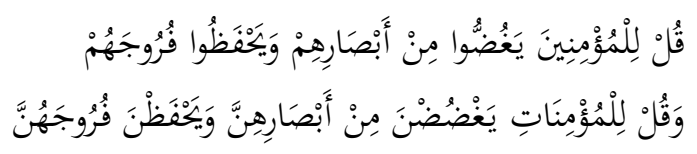

Terjemahnya:

"Katakanlah kepada orang laki-laki yang beriman: Hendaklah mereka menahan pandanganya, dan memelihara kemaluannya" 33 .

"Katakanlah kepada wanita yang beriman: Hendaklah mereka menahan pandangannya, dan kemaluannya" ${ }^{4}$.

Di sisi lain, makna tradisi Akkorontigi juga menunjukkan sikap kesiapan menerima amanah. Calon mempelai menengadahkan kedua tangannya dengan suatu makna yang terkandung, adalah kesiapan untuk menerima amanah dalam berumah tangga. Kesiapan untuk mengetahui dan menghayati seluk beluk hak dan kewajiban masing-masing, agar bahtera rumah tangga dapat terjalin dengan baik dan harmonis. Adapun hak dan kewajiban masing-masing pihak (suami dan isteri) dalam mengembang amanah telah diuraikan dengan gamblang dalam nas Al-Qur'an dan sunah ${ }^{35}$. Berbeda halnya dengan tradisi Mappasikarawa yang juga dilakukan sebelum akad nikah, dan kedua mempelai pengantin dipertemukan dan terjadi persentuhan fisik, sehingga terdapat pelanggaran syariat di dalamnya ${ }^{36}$.

November 2019).

${ }^{32}$ Nurliah, 57 Tahun, Anrong Bunting, Wawancara, Bontotangnga Desa Bontosunggu, (26

${ }^{33}$ Kementerian Agama Republik Indonesia, Al-Qur'an dan Terjemahnya, 353.

${ }^{34}$ Kementerian Agama Republik Indonesia, Al-Qur'an dan Terjemahnya, 353.

${ }^{35}$ Agus Salim, Risalah Nikah (Cet.III; Jakarta: Pustaka Amani, 1998), 110.

${ }^{36}$ Syandri, Kasman Bakry, and Salman Al Farisi. "Adat Mappasikarawa pada Perkawinan Masyarakat Bugis Perspektif Hukum Islam (Studi Kasus Desa Kaballangan Kabupaten Pinrang)." BUSTANUL FUQAHA: Jurnal Bidang Hukum Islam 1.4 (2020): 611. 


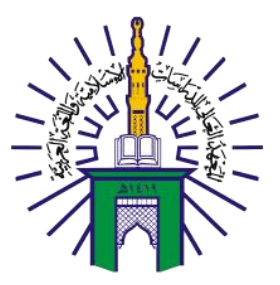

BUSTANUL FUQAHA:

JURNAL BIDANG HUKUM ISLAM

Vol. 2 No. 1 (2021): Hal. 59-77

EISSN: 2723-6021

Website: https://journal.stiba.ac.id

\section{Kaidah Ushul dalam Menimbang Tradisi Akkorongtigi}

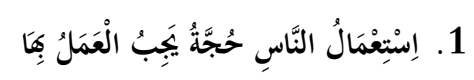

Artinya:

Kebiasaan umum adalah dasar yang harus dipatuhi ${ }^{37}$.

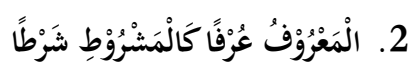

Artinya:

Adanya apa yang dikehendaki oleh adat dianggap sebagai hal yang dikehendaki oleh syara ${ }^{38}$.

3. النَّابتُ بِالْعُرْفِ كَالنَّابِتِ بِالنَّصِّ

Artinya:

Kebiasaan umum adalah dasar yang harus dipatuhi ${ }^{39}$.

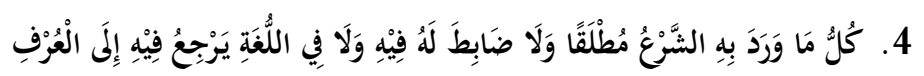

Artinya:

Semua yang diatur oleh syara' secara mutlak namun belum ada ketentuan dalam agama serta dalam bahasa maka semua itu dikembalikan kepada ' $U r f^{40}$.

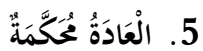

Artinya:

Adat kebiasaan itu bisa menjadi hukum ${ }^{41}$.

Adapun adat atau kebiasaan dapat diterima sebagai hukum apabila memenuhi syarat sebagai berikut:

1. Perbuatan yang dilakukan logis dan relevan dengan akal sehat, syarat ini menunjukkan bahwa adat tidak mungkin berkenan dengan perbuatan maksiat.

2. Perbuatan atau perkataan yang dilakukan selalu berulang, sering menjadi boleh dikata sudah mendarah daging bagi perilaku masyarakat.

${ }^{37}$ Muhammad al-Khuḍarī Bik, Tārikh al-Tasyrī’ al-Islāmī (Cet. VII; Indonesia: Dār Ihyā' al'Arabiyyah, $1401 \mathrm{H} / 1971 \mathrm{M}), 17$.

${ }^{38}$ Aḥmad 'Abd al-Majīd, Muḥaḍarāt fi Ușūl al-Fiqh (Cet. IV; Pasuran: Garuda Buana Indah,1994), 86.

39،Abd al-Wahhāb al-Khallāf, Ilm Ușūl al-Fiqh (Cet. XIII; Kairo: Dār al-Qalam,1398 H/1978 M),

90.

40،Abd al-Hamīd Hakīm, al-Sullām, Juz 2 (Jakarta: Sa’adiyah Putra, t.th), 37.

${ }^{41}$ Muslim ibn Muḥammad ibn Mājid al-Dausarī, al-Mumti' fi al-Qawā'id al-Fiqhiyyah, (Cet. I; Riyadh: Dār Zidn̄̄, 1428 H/2007), 267. 


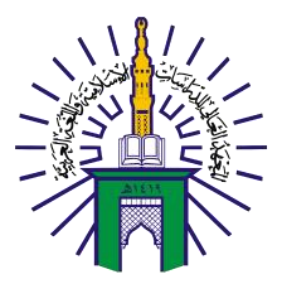

\section{BUSTANUL FUQAHA: \\ JURNAL BIDANG HUKUM ISLAM \\ Vol. 2 No. 1 (2021): Hal. 59-77 \\ EISSN: 2723-6021 \\ Website: https://journal.stiba.ac.id}

3. Tidak bertentangan dengan nas baik Al-Qur'an maupun sunah.

4. Tidak akan mendatangkan kemudaratan serta sejalan dengan jiwa dan akal yang sehat.

Imam Muhammad Izuddin bin Abd. Al-Salim menyimpulkan bahwa pada dasarnya kaidah Asasiyah dan kaidah Fiqhihyah dapat dikristalkan menjadi kaidah:

$$
\text { دَرْءُ الْمَفَاسِدِ أَوْلَى مِنْ جَلْبِ الْمَصَالِحِ }
$$

Artinya:

Menolak kerusakan lebih diutamakan dari menarik kemaslahatan. ${ }^{42}$

Setelah dikemukakan pandangan tentang pandangan hukum Islam tentang adat, maka dalam mengemukakan dasar-dasar atau keterangan tentang pelaksanaan sesuatu dalam hukum Islam, maka kaidah ushul menyatakan:

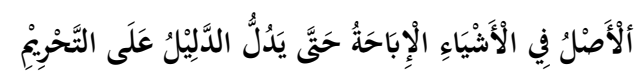

Artinya:

Pada dasarnya setiap sesuatu itu adalah kebolehan sampai ada dalil yang menunjukkan keharamannya ${ }^{43}$.

Kaidah tersebut juga didasarkan pada firman Allah swt. dalam Al-Qur'an Qs. AlBaqarah/2:29 yang berbunyi:

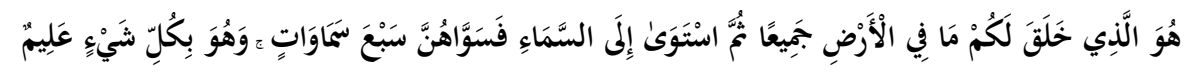

Terjemahnya:

"Dialah Allah, yang menjadikan segala yang ada di bumi untuk kamu dan Dia berkehendak (menciptakan) langit, lalu dijadikan-Nya tujuh langit dan Dia Maha mengetahui segala sesuatu"44.

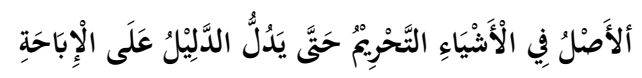

Artinya:

Pada dasarnya, setiap sesuatu diharamkan, sampai adanya dalil yang membolehkannya ${ }^{45}$.

Dalam kaidah di atas, dari segi maknanya bertentangan, namun dapat dikompromikan, yaitu dengan jalan meletakkan dan menggunakan kaidah sesuai dengan

\footnotetext{
${ }^{42}$ Muslim ibn Muḥammad ibn Mājid al-Dausarī, al-Mumti' fi al-Qawā'id al-Fiqhiyyah, 253.

${ }^{43}$ Muslim ibn Muḥammad ibn Mājid al-Dausarī, al-Mumti' fi al-Qawā'id al-Fiqhiyyah, 141.

${ }^{44}$ Kementerian Agama Republik Indonesia, Al-Qur'an dan Terjemahnya, 5.

${ }^{45}$ Muslim ibn Muhammad ibn Mājid al-dausarī, al-Mumti' fi al-Qawā 'id al-Fiqhiyyah, 141.
} 


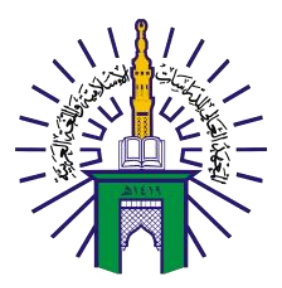

\section{BUSTANUL FUQAHA: \\ JURNAL BIDANG HUKUM ISLAM \\ Vol. 2 No. 1 (2021): Hal. 59-77 \\ EISSN: 2723-6021 \\ Website: https://journal.stiba.ac.id}

proporsinya. Kaidah pertama lebih tepat digunakan dalam masalah muamalah dan keduniaan, sedangkan kaidah kedua khusus masalah ibadah ${ }^{46}$. Oleh karena dalam masalah ibadah, hakekatnya segala sesuatu perbuatan harus menunggu adanya perintah, sebagaimana kaidah:

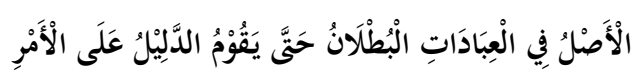

Artinya:

Hukum asal dari ibadah adalah batal hingga ada dalil yang memerintahkannya. ${ }^{47}$

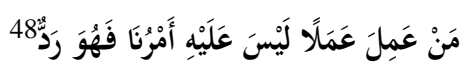

Artinya:

Barangsiapa yang mengada-ngadakan sesuatu (amalan) dalam urusan (agama) kami yang bukan dari kami, maka amalan itu tertolak. (H.R. Bukhari)

Setelah memaparkan berbagai pertimbangan dan dasar-dasar dari Al-Qur'an, hadis maupun kaidah ushul fikih tentang adat serta hukum pelaksanaan sesuatu hal, maka diperoleh gambaran tentang pandangan hukum Islam tentang tradisi Akkorontigi khususnya di Desa Bontosunggu Kecamatan Bajeng Kabupaten Gowa. Pelaksanaan tradisi Akkorontigi dalam pernikahan, adalah tetap dipelihara dan dipertahankan karena termasuk salah satu adat (kebiasaan) yang dianggap baik dalam rangkaian proses perkawinan masyarakat di Desa Bontosunggu Kecamatan Bajeng Kabupaten Gowa secara khusus, dan masyarakat Makassar secara umum serta secara keseluruhan pelaksanaannya tidak bertentangan dengan hukum Islam, namun masih ada hal-hal yang masih ingin disempurnakan.

Dalam prosesi perkawinan di masyarakat Desa Bontosunggu Kecamatan Bajeng Kabupaten Gowa yaitu pakaian calon mempelai wanita harus menutupi aurat dan tidak tipis. Solusinya adalah tetap memakai pakaian adat yang telah diformat dan disempurnakan, serta sejalan dengan syariat dan tidak bersentuhan dengan lawan jenis yang bukan muhram seperti yang terjadi dalam prosesi Akkorontigi di mana para tamu undangan memberikan Pacci ke tangan calon pengantin karena hal tersebut haram hukumnya. Hal ini sesuai dengan hadis nabi, dari Ma'qil bin Yasār, Rasulullah saw. bersabda:

${ }^{46}$ Abd. Mudjib, Kaidah-Kaidah Fikih (Cet. I; Jakarta: Kalam Mulia, 1994), 25.

${ }^{47}$ Muslim ibn Muḥammad ibn Mājid al-dausarī, al-Mumti' fi al-Qawā'id al-Fiqhiyyah, 141.

${ }^{48}$ Muḥammad ibn Ismā’̄̄il ibn Ibrāhīm al-Bukhārī, Șahīh al-Bukhārī (Cet. I; al-Qāhirah: Dār ibn alJauzī, 2010), 318. 

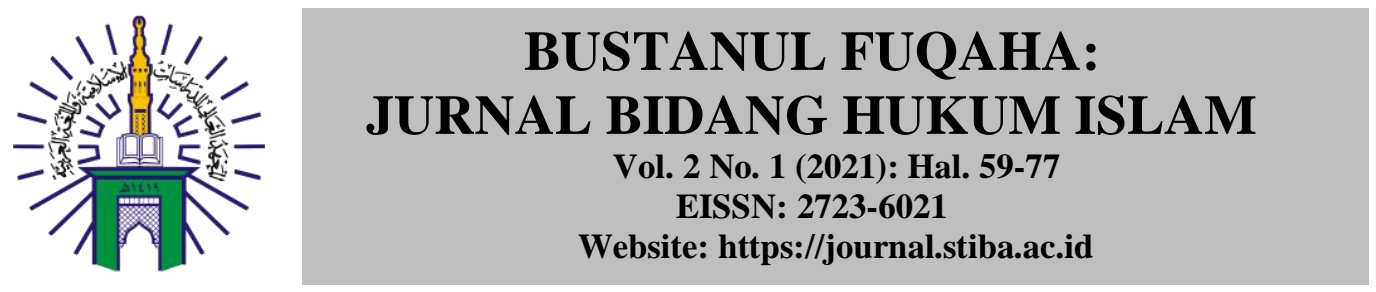

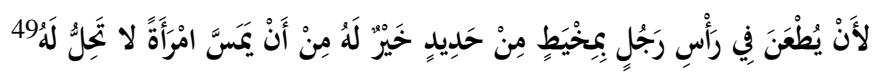

Artinya:

Ditusuknya kepala seseorang dengan pasak dari besi, sungguh lebih baik baginya daripada menyentuh wanita yang bukan mahramnya. (H.R. Tabrani).

Selain itu, kita juga harus menghindarkan diri dari meramalkan hal-hal yang tidak sesuai dengan syariat. Dalam prosesi Akkorontigi seperti simbol pada lilin yang dapat memberikan penerangan, mudah-mudahan Allah swt. betul-betul memberikan petunjuk dan penerangan kepada kita semua. Adapun keyakinan akan datangnya musibah atau mudah tertimpa bencana ketika tidak melaksanakan tradisi tersebut bagi kedua calon mempelai, adalah merupakan pikiran-pikiran atau keyakinan yang dapat merusak akidah kita kepada Allah swt. dan jatuh dalam lembah kemusyrikan bagi sang pelaku, terlebih bila tidak dapat menjaga niatnya dengan baik.

\section{KESIMPULAN}

Berdasarkan data wawancara dan observasi, prosesi Akkorontigi merupakan tradisi nenek moyang terdahulu yang terdapat di masing-masing daerah Makassar Sulawesi Selatan yang memiliki makna mendalam sehingga masyarakat beranggapan baahwa hal tersebut harus dijaga dan dilestarikan. Makna yang terkandung dalam prosesi Akkorontigi mempunyai harapan yang sangat besar didalamnya agar calon mempelai memiliki hati yang bersih dan suci sebelum menggelar akad, mendapatkan doa restu dari para keluarga, kerabat dan para tamu undangan agar kelak mereka dianugerahi kebahagiaan dan kesejahteraan dalam mengarungi bahtera rumah tangga.

Dalam prosesi Akkorontigi, ada beberapa alat dan bahan yang harus dipersiapkan sebelum melaksanakan ritual tersebut, diantaranya yaitu: Bantal, lilin merah, sarung sutera, Pacci, daun pisang, dan wadah Pacci, juga terkadang ada yang menambahkannya dengan daun nangka, gula merah dan kelapa. Terdapat berbagai macam makna yang begitu mendalam pada alat dan bahan yang digunakan tersebut, sehingga terkadang masyarakat ingin melakukan ritual Akkorontigi itu sendiri tanpa memikirkan dampak yang akan terjadi apabila mereka salah menempatkan niatnya, terlebih tidak mempertimbangkan syariat Islam.

Oleh karena itu, hukum Islam beranggapan bahwasanya adat (tradisi) itu tidak mengapa kita jaga, asalkan sesuai dengan tuntunan Al-Qur'an, sunah nabi, serta kaidahkaidah yang terdapat dalam ushul fikih. Dalam prosesi pelaksanaan Akkorontigi, ada beberapa hal yang tidak sesuai dengan syariat Islam seperti ketika para tamu undangan meletakkan Pacci di telapak tangan calon mempelai, otomatis hal tersebut merupakan

${ }^{49}$ Sulaimān ibn Aḥmad ibn Ayyūb al-Ṭabrān̄̄, al-Mu'jam al-Kabīr, Juz 20 (Cet. II; al-Qāhirah: Maktabah ibn Taimiyyah, t.th.), 211. 


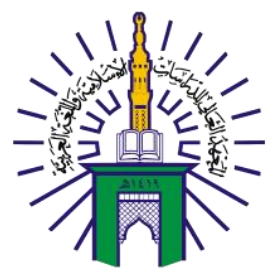

\section{BUSTANUL FUQAHA: \\ JURNAL BIDANG HUKUM ISLAM \\ Vol. 2 No. 1 (2021): Hal. 59-77 \\ EISSN: 2723-6021 \\ Website: https://journal.stiba.ac.id}

suatu hal yang sangat dilarang oleh agama, karena mereka bersentuhan dengan laki-laki atau perempuan yang bukan muhram baginya. Begitu pula pakaian yang digunakan dalam tradisi tersebut, belum sesuai dengan tuntunan syariat, maka solusinya adalah tidak mengapa memakai pakaian adat apabila pakaian tersebut sudah diformat menjadi bentuk modern dan menutupi aurat sesuai dengan konteks syariat Islam. Sehubungan dengan itu pula, yang terpenting adalah masyarakat dapat menjaga niatnya dengan tidak menaruh harapan pada alat dan bahan yang digunakan dalam prosesi tersebut. Terlebih pada pikiran atau keyakinan yang menjatuhkan masyarakat ke dalam lembah kesyirikan.

\section{DAFTAR PUSTAKA}

Al-Bukhārī, Muḥammad ibn Ismā’îl ibn Ibrāhīm, Șahīh al-Bukhārī (Cet. I; al-Qāhirah: Dār ibn al-Jauzī, 2010.

Al-Dausarī, Muslim ibn Muhammad ibn Mājid. Al-Mumti' fi al-Qawā'id al-Fiqhiyyah, Cet. I; Riyadh: Dār Zidn̄̄, 1428 H/2007.

'Al-Khallāf, Abd al-Wahhāb. Ilm Ușūl al-Fiqh, Cet. XIII; Kairo: Dār al-Qalam, 1398 H/1978 M.

Al-Khuḍarī Bik, Muḥammad. Tārikh al-Tasyrī’ al-Islāmī, Cet. VII; Indonesia: Dār Iḥ̂ā’ al-'Arabiyyah, $1401 \mathrm{H} / 1971 \mathrm{M}$.

Al-Majīd, Aḥmad 'Abd. Muhadarāt fi Ușūl al-Fiqh, Cet. IV; Pasuran: Garuda Buana Indah,1994.

Al-Ṭabrānī, Sulaimān ibn Aḥmad ibn Ayyūb, al-Mu'jam al-Kabīr, Juz 20 (Cet. II; alQāhirah: Maktabah ibn Taimiyyah, t.th.

Gaffar, Abd. Peranan Al-'urf dalam Mengistimbatkan Hukum Islam, Skripsi, Mangkoso, Fakultas Syariah STAI DDI Mongkoso, 2003.

Hanafi, Ahmad. Pengantar dan Sejarah Hukum Islam, Cet.II; Jakarta: Bulan Bintang, 1997.

Kementerian Agama Republik Indonesia, Al-Qur'an dan Terjemahnya. Jakarta: Syaamil quran, 2014.

Mudjib, Abd. Kaidah-Kaidah Fikih, Cet. I; Jakarta: Kalam Mulia, 1994.

Novira, Nuraeni, and Auliani Ahmad. "Tinjauan Akidah Islam terhadap Adat Mappalili di Balla Lompoa Kelurahan Baju Bodoa Kecamatan Maros Baru Kabupaten Maros Sulawesi Selatan." NUKHBATUL'ULUM: Jurnal Bidang Kajian Islam 5.1 (2019): 15-25.

Salim, Agus. Risalah Nikah, Cet.III; Jakarta: Pustaka Amani, 1998.

Saransi, Ahmad. Tradisi Masyarakat Islam di Sulawesi Selatan, Cet. I; Makassar: Lamanca Press, 2003.

Soekamto, Sujono. Sosiologi Suatu Pengantar, Jakarta: Raja Grafindo, 2001.

Syandri, Syandri, Kasman Bakry, and Salman Al Farisi. "Adat Mappasikarawa pada Perkawinan Masyarakat Bugis Perspektif Hukum Islam (Studi Kasus Desa 


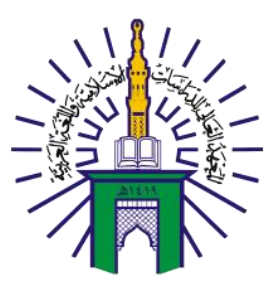

\section{BUSTANUL FUQAHA: \\ JURNAL BIDANG HUKUM ISLAM \\ Vol. 2 No. 1 (2021): Hal. 59-77 \\ EISSN: 2723-6021 \\ Website: https://journal.stiba.ac.id}

Kaballangan Kabupaten Pinrang)." BUSTANUL FUQAHA: Jurnal Bidang Hukum Islam 1.4 (2020): 611-626.

Wijaya, Hendra, and Fadlan Akbar. "Tradisi Te'nea dalam Perspektif Hukum Islam (Studi

Kasus di Desa Majannang)." NUKHBATUL'ULUM: Jurnal Bidang Kajian Islam 6.1 (2020): 145-158.

Yahya Muhtar, Fatehurahman. Dasar-Dasar Pembinaan Hukum Fikih Islam, Cet. I; Bandung: Al-Ma'rif, 2001.

\section{Sumber Wawancara:}

Asdar DM, A.Md., 35 Tahun, Sekretaris II Desa Bontosunggu, Wawancara, Bontotangnga Desa Bontosunggu, (5 Desember 2019)

Daeng Kanang (44 tahun), Pemangku adat, Wawancara, Bontotangnga Desa Bontosunggu, 25 November 2019.

Fatmawati (35 tahun), Masyarakat Bontotangnga Desa Bontosunggu, Wawancara, Gowa, 20 September 2019.

Hapipa Daeng Calla, 71 Tahun, Masyarakat Desa Bontosunggu, Wawancara, Bontotangnga Desa Bontosunggu, (7 Desember 2019).

Nurliah, 57 Tahun, Anrong Bunting, Wawancara, Bontotangnga Desa Bontosunggu, (26 November 2019).

Zaenab, 62 Tahun, Objek atau Pelaku Akkorontigi, Wawancara, Bontotangnga Desa Bontosunggu, (9 Desember 2019). 